\title{
Modulated bonding interaction in propanediol electrolytes toward stable aqueous zinc-ion batteries
}

\author{
Tingting Wei ${ }^{1,2}$, Yuqi Peng ${ }^{1,2}$, Li'e Mo ${ }^{1,2}$, Shuanghong Chen ${ }^{1}$, Rahim Ghadari ${ }^{3}$, Zhaoqian $\operatorname{Li}^{{ }^{*}}$ and \\ Linhua $\mathrm{Hu}^{1 *}$
}

\begin{abstract}
Aqueous Zn-based batteries are promising energy storage technology due to their low cost and high safety. However, the solvation structure of electrolyte leads to dendrite growth, parasitic reactions, and poor low-temperature properties, limiting their practical application. Here, we report 1,2-propanediol (PG) electrolyte with a modulated solvation structure, which can suppress $\mathrm{Zn}$ dendrite growth and parasitic reactions. $P G$ can break the interaction between $\mathrm{H}_{2} \mathrm{O}$ molecules and the interaction between $\mathrm{H}_{2} \mathrm{O}$ and $\mathrm{Zn}^{2+}$ due to the higher electron density of $\mathrm{O}$ and higher Gutmann donor number of PG than those of $\mathrm{H}_{2} \mathrm{O}$, which increase the $\mathrm{H}-\mathrm{O}$ covalent bond strength, decrease the water activity and freezing point, and change the solvation structure of $\mathrm{Zn}^{2+}$. As a result, the battery exhibits high cycling stability $(\mathrm{Zn} / / \mathrm{Zn}$ battery cycle over $1000 \mathrm{~h}$ ), high reversibility (Coulombic efficiency of $98.9 \%$ ), high capacity properties (specific capacity of $225 \mathrm{~mA} \mathrm{~h} \mathrm{~g}^{-1}$ at $5 \mathrm{~A} \mathrm{~g}^{-1}$, and capacity retention of $92.6 \%$ for 5000 cycles), and excellent anti-freezing properties (specific capacity of $190 \mathrm{~mA} \mathrm{~h} \mathrm{~g}^{-1}$ at $-20^{\circ} \mathrm{C}$ over 500 cycles). This work provides a promising strategy for the development of highperformance aqueous zinc-ion batteries.
\end{abstract}

Keywords: electrolyte, Gutmann donor number, low-temperature, aqueous zinc-ion battery

\section{INTRODUCTION}

Lithium-ion batteries have recently dominated most of the market, but their widespread application is hindered by their rare natural sources, safety issues, and environmental unfriendliness [1-6]. However, zinc is relatively abundant, cheap and stable on the Earth and possesses high compatibility with air and water, which is beneficial to its practical operation [7-11]. Because of the multiple electron transfer, zinc-ion batteries have a higher storage capacity than lithium-ion batteries [12]. The zinc-ion battery has emerged as a promising energy storage technology in recent years due to its high safety, low cost, abundant reserves, and good compatibility with cathode materials and aqueous electrolytes, as well as the low redox potential $(-0.76 \mathrm{~V}$ vs. standard hydrogen electrode) and high theoretical capacity $\left(820 \mathrm{~mA} \mathrm{~h} \mathrm{~g}^{-1}\right)$ of $\mathrm{Zn}$ metal anode [13-17]. However, several issues remain in the development of aqueous zinc-ion battery, such as dendrite, irreversible plating/stripping, and poor low-temperature properties. Serious corrosion, pierced separator, and battery failure can all result from these issues. A coating layer $[18,19]$, a three-dimensional (3D) porous anode [20,21], a separator [22], and electrolyte $[23,24]$ have all been proposed as solutions to the problems. Generally, designing electrolytes is a simple and effective method, including high concentration [25], organic [26], polymer [27], and additive-assisted electrolyte [28]. Among them, the use of an additive-electrolyte is a cost-effective and safe strategy.

The parasitic water reaction caused by abundant water in the electrolyte is the primary reason for dendrite and failure [29]. The unshared electron pair in water acts as a strong Lewis base to interact with cations, which occupies the solvation shell of cations, resulting in the water around cations [30]. Six water molecules surround a zinc ion in an aqueous zinc-ion battery. Water can be split into $\mathrm{H}_{2}$ during the plating/stripping of $\mathrm{Zn}$ metal; the local $\mathrm{pH}$ environment change leads to the formation of by-products $\mathrm{Zn}(\mathrm{OH})_{2}, \mathrm{Zn}_{4} \mathrm{SO}_{4}(\mathrm{OH})_{6} \cdot x \mathrm{H}_{2} \mathrm{O}$, and so on [31]. Therefore, reducing the activity and amount of water can alleviate these problems. Moreover, aqueous electrolytes contain a large amount of water, which has a high freezing point, restricting the operation at low temperatures. Alcohols, such as methanol [32] and ethylene glycol [33-35], have recently been shown to be effective additives, significantly improving battery performance and decreasing the freezing point. Inspired by these discoveries, we hypothesize that 1,2-propanediol (PG) would be a superior additive with a higher Gutmann donor number than water. The electron donor ability of molecules is represented by Gutmann donor numbers [36], which can reflect the bonding tendency between the molecules and $\mathrm{Zn}^{2+}$ (the $\mathrm{Zn}^{2+}$ is regarded as an electron acceptor).

As shown in Table S1, most alcohols have a higher Gutmann donor number than $\mathrm{H}_{2} \mathrm{O}$ (18) due to the higher electron density of $\mathrm{OH}$ in alcohols, e.g., methanol (20.4), ethylene glycol (21.8), 1-butanol (22.1), and so on [37]. Similarly, PG as a kind of alcohol with $\mathrm{OH}$ should possess a higher donor number than water and preferentially interact with cations. Here, we show that adding PG into the $\mathrm{ZnSO}_{4}$ electrolyte of the aqueous reversible zinc-ion battery can improve battery performance by expanding the electrochemical stability window, lowering the freezing point, and suppressing the dendrite formation and side-

\footnotetext{
${ }^{1}$ Key Laboratory of Photovoltaic and Energy Conservation Materials, CAS, Institute of Solid State Physics, Hefei Institutes of Physical Science, Chinese Academy of Sciences, Hefei 230031, China

${ }^{2}$ University of Science and Technology of China, Hefei 230026, China

${ }^{3}$ Computational Chemistry Laboratory, Department of Organic and Biochemistry, Faculty of Chemistry, University of Tabriz, 5166616471 Tabriz, Iran

*Corresponding authors (emails: zqli@rntek.cas.cn (Li Z); lhhu@rntek.cas.cn (Hu L))
} 
reactions on the $\mathrm{Zn}$ anode. Owing to the higher donor number of PG than $\mathrm{H}_{2} \mathrm{O}$, PG can preferentially conscript the cosolvents in the structure of solvation sheath of $\mathrm{Zn}^{2+}$, change the $\mathrm{Zn}^{2+}$ solvation structure, and suppress the parasitic reaction, leading to improved zinc-ion storage performance. Therefore, this strategy is scalable and promising for high-performance rechargeable aqueous zinc-ion batteries.

\section{EXPERIMENTAL SECTION}

\section{Material preparation}

Electrolyte synthesis: All chemicals and reagents were used directly without further purification. The $3 \mathrm{~mol} \mathrm{~L}^{-1} \quad \mathrm{ZnSO}_{4}$ solution was prepared firstly through the constant volume method by adding $0.03 \mathrm{~mol}$ of $\mathrm{ZnSO}_{4} \cdot 7 \mathrm{H}_{2} \mathrm{O}$ (Sinopharm Group, analytical reagent (AR)) into $0.313 \mathrm{~mol}$ of $\mathrm{H}_{2} \mathrm{O}$ (self-made by Milli-Q). The $\mathrm{ZnSO}_{4} / \mathrm{PG}$ hybrid electrolytes were prepared by mixing PG (Sinopharm Group, AR) with $3 \mathrm{~mol} \mathrm{~L}^{-1} \mathrm{ZnSO}_{4}$ solution at a series of volume ratios $(5 \%, 10 \%, 20 \%, 30 \%$, and $50 \%)$.

Cathode material synthesis: A hydrothermal method was used to synthesize the $\mathrm{V}_{2} \mathrm{O}_{5}$ powder. Commercial $\mathrm{V}_{2} \mathrm{O}_{5}(10 \mathrm{mmol}$, Alfa Aesar) was dissolved in a mixture solution containing $30 \mathrm{~mL}$ of deionized water and $20 \mathrm{~g}$ of ethylene glycol (Sinopharm Group) under vigorous stirring to obtain a homogeneous solution. The mixture was transferred to a $100-\mathrm{mL}$ autoclave and heated at $200^{\circ} \mathrm{C}$ for $24 \mathrm{~h}$. The collected products were centrifuged, washed, and dried for $12 \mathrm{~h}$ at $80^{\circ} \mathrm{C}$ after cooling to room temperature. The collected $\mathrm{V}_{2} \mathrm{O}_{5}$ powder was prepared by annealing the as-obtained products at $330^{\circ} \mathrm{C}$ for $30 \mathrm{~min}$ with a heating rate of $2^{\circ} \mathrm{C} \mathrm{min}^{-1}$.

\section{Material characterization}

A field emission scanning electron microscope (FESEM, AURIGA) with an accelerating voltage of $10.0 \mathrm{kV}$ was used to obtain the morphologies and energy dispersive spectroscopy (EDS) mapping images of $\mathrm{V}_{2} \mathrm{O}_{5}$ powder and the electrode. The Rigaku SmartLab 9KW X-ray diffractometer was used to obtain X-ray diffraction (XRD) patterns using $\mathrm{Cu}-\mathrm{Ka}$ radiation $(\lambda=$ $1.540593 \mathrm{~nm})$. The nuclear magnetic resonance (NMR) spectra were acquired on a Bruker AVANCE AV III 400 spectrometer using $\mathrm{D}_{2} \mathrm{O}$ as the field frequency lock. The electrolyte structure was investigated using a Fourier transform infrared (FTIR) spectrometer (iS50R). The freezing point was tested by differential scanning calorimetry (DSC) through a TA-Q2000 Instrument from -60 to $20^{\circ} \mathrm{C}$ at a heating rate of $2^{\circ} \mathrm{C} \mathrm{min}^{-1}$. A conductivity meter (FE28, Mettler Toledo) was used to determine the ionic conductivity of electrolytes. A phone's camera was used to take digital photos of the battery and separator. The low-temperature properties were tested in the refrigerator with a temperature ranging from -18.6 to $-21.2^{\circ} \mathrm{C}$ and all samples were rested in the refrigerator over $24 \mathrm{~h}$ before being tested.

\section{Electrochemical measurements}

The synthetic $\mathrm{V}_{2} \mathrm{O}_{5}$ powder $\left(\mathrm{S}-\mathrm{V}_{2} \mathrm{O}_{5}\right)$ was mixed with active carbon (conductive additive) and polyvinylidene fluoride (binder) with a weight ratio of 7:2:1 to make the $\mathrm{V}_{2} \mathrm{O}_{5}$ cathode. The slurry was stirred vigorously and then spread onto $14-\mathrm{mm}$ stainless steel mesh (500 mesh) and dried in an oven at $80^{\circ} \mathrm{C}$ for $5 \mathrm{~h}$. The batteries were assembled with the cathode, anode and separator using the CR2030-type coin cells in the air atmo- sphere. The electrochemical windows of an electrolyte were tested using a CHI660E electrochemical workstation with stainless steel as the cathode and $\mathrm{Zn}$ as the anode from -0.2 to $2.6 \mathrm{~V}$ at a scan rate of $1 \mathrm{mV} \mathrm{s}^{-1}$ to determine the linear sweep voltammetry (LSV) curves. The ohmic-corrected cyclic voltammogram (CV) curves were measured to test the $\mathrm{Zn}^{2+}$ deposition potential of electrolytes by the CHI660E electrochemical workstation with stainless steel as the cathode and $\mathrm{Zn}$ as the anode from -0.2 to $0.6 \mathrm{~V}$ with a scan rate of $1 \mathrm{mV} \mathrm{s}^{-1}$. The CHI660E electrochemical workstation was used to perform the $\mathrm{CV}$ of full battery from 0.3 to $1.6 \mathrm{~V}$. The BTS 3000 Netware Battery Testing System generated the galvanostatic charge/discharge (GCD) profiles.

\section{RESULTS AND DISCUSSION}

\section{Properties of $\mathrm{ZnSO}_{4} / \mathrm{H}_{2} \mathrm{O} / \mathrm{PG}$ electrolyte}

FTIR, NMR, and theoretical calculations were used to investigate the influence of PG on hybrid electrolytes at the molecular level. Compared with the pure $\mathrm{H}_{2} \mathrm{O}$ (Fig. 1a), the FTIR spectra of $\mathrm{H}_{2} \mathrm{O} / \mathrm{PG}$ show a slight blue shift at $3000-3500 \mathrm{~cm}^{-1}$ of $\mathrm{OH}$ stretching vibration and $\mathrm{H}_{2} \mathrm{O}$ bending vibration at $1600-1700 \mathrm{~cm}^{-1}$, implying the disturbed hydrogen bonding interaction between $\mathrm{H}_{2} \mathrm{O}$ molecules by $\mathrm{PG}[38,39]$. Due to the higher electron density of $\mathrm{O}$ in $\mathrm{PG}$ than that in $\mathrm{H}_{2} \mathrm{O}$ [33], the tendency of the oxygen atom (in PG) to attract electrons is lower than that in water, leading to a weakened hydrogen bonding between $P G$ and $\mathrm{H}_{2} \mathrm{O}$ than between $\mathrm{H}_{2} \mathrm{O}$ and $\mathrm{H}_{2} \mathrm{O}$, resulting in the enhanced $\mathrm{H}-\mathrm{O}$ covalent bond in the water molecules and the shift of the corresponding FTIR spectra. The higher absorbed wavenumber of the $\mathrm{H}-\mathrm{O}$ bond indicates the increased $\mathrm{H}-\mathrm{O}$ covalent bond strength of $\mathrm{H}_{2} \mathrm{O}$ in $\mathrm{PG}$ electrolyte, which can increase the stability of electrolyte [40]. NMR analysis can be used to further characterize the interaction between $\mathrm{PG}$ and $\mathrm{H}_{2} \mathrm{O}$. As shown in Fig. 1 b, the ${ }^{1} \mathrm{H}$ of $\mathrm{H}_{2} \mathrm{O}$ shifts to higher field with increasing $\mathrm{PG}$ content, indicating there is higher electron density around the $\mathrm{H}$ atoms with increasing PG content, which means more electron shielding. The hydrogen-bonding interaction between the $\mathrm{O}$ atom in $\mathrm{PG}$ and the $\mathrm{H}$ atom in $\mathrm{H}_{2} \mathrm{O}$ can be attributed to this result [41]. Fig. 1c shows the FTIR spectra of $\mathrm{H}_{2} \mathrm{O} / \mathrm{PG} / \mathrm{ZnSO}_{4}$ electrolyte. Compared with pure $\mathrm{ZnSO}_{4}$ electrolyte, the $v\left(\mathrm{SO}_{4}{ }^{2-}\right)$ vibration shifts to a higher wavenumber with the addition of $\mathrm{PG}$, which is similar to the vibration wavenumber of $\mathrm{ZnSO}_{4}$ powder at $\sim 1092.4 \mathrm{~cm}^{-1}$ [42], implying that PG can break the solvation sheath structure of $\mathrm{Zn}^{2+}$ [43]. Density functional theory (DFT) calculation was used to compare the relative binding energies between different molecules to further validate the connection tendency of molecules. As shown in Fig. 1d, the relative binding energies between different molecules are ranked in the order of $\mathrm{PG}-\mathrm{H}_{2} \mathrm{O}>\mathrm{H}_{2} \mathrm{O}-\mathrm{H}_{2} \mathrm{O}$ and $\mathrm{Zn}^{2+}-\mathrm{PG}>\mathrm{Zn}^{2+}-\mathrm{H}_{2} \mathrm{O}$, implying that the connection between $\mathrm{PG}$ and $\mathrm{H}_{2} \mathrm{O}$ is easier to form and the $\mathrm{Zn}^{2+}$ tends to connect with PG. Therefore, the addition of PG can break the interaction of $\mathrm{H}_{2} \mathrm{O}-\mathrm{H}_{2} \mathrm{O}$ and $\mathrm{Zn}^{2+}-\mathrm{H}_{2} \mathrm{O}$. The main influence mechanism of $\mathrm{PG}$ on electrolytes is shown in Fig. 1e. A hydrogen-bonding interaction is formed between $\mathrm{PG}$ and $\mathrm{H}_{2} \mathrm{O}$ due to the higher electron density of $\mathrm{O}$ in $\mathrm{PG}$ than in $\mathrm{H}_{2} \mathrm{O}$. Besides, because $\mathrm{PG}$ has a higher donor number than $\mathrm{H}_{2} \mathrm{O}$, it is easier for it to interact with $\mathrm{Zn}^{2+}$, which weakens the interaction between $\mathrm{H}_{2} \mathrm{O}$ and $\mathrm{Zn}^{2+}$ and enhances the interaction between PG and $\mathrm{Zn}^{2+}$. The addition of PG can decrease the hydrogen bonding between water mole- 

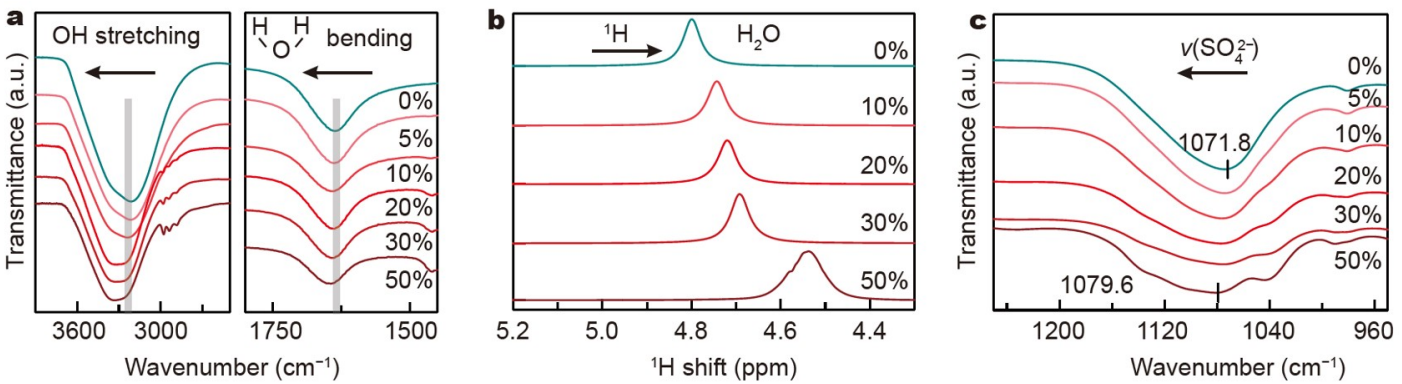

d



e
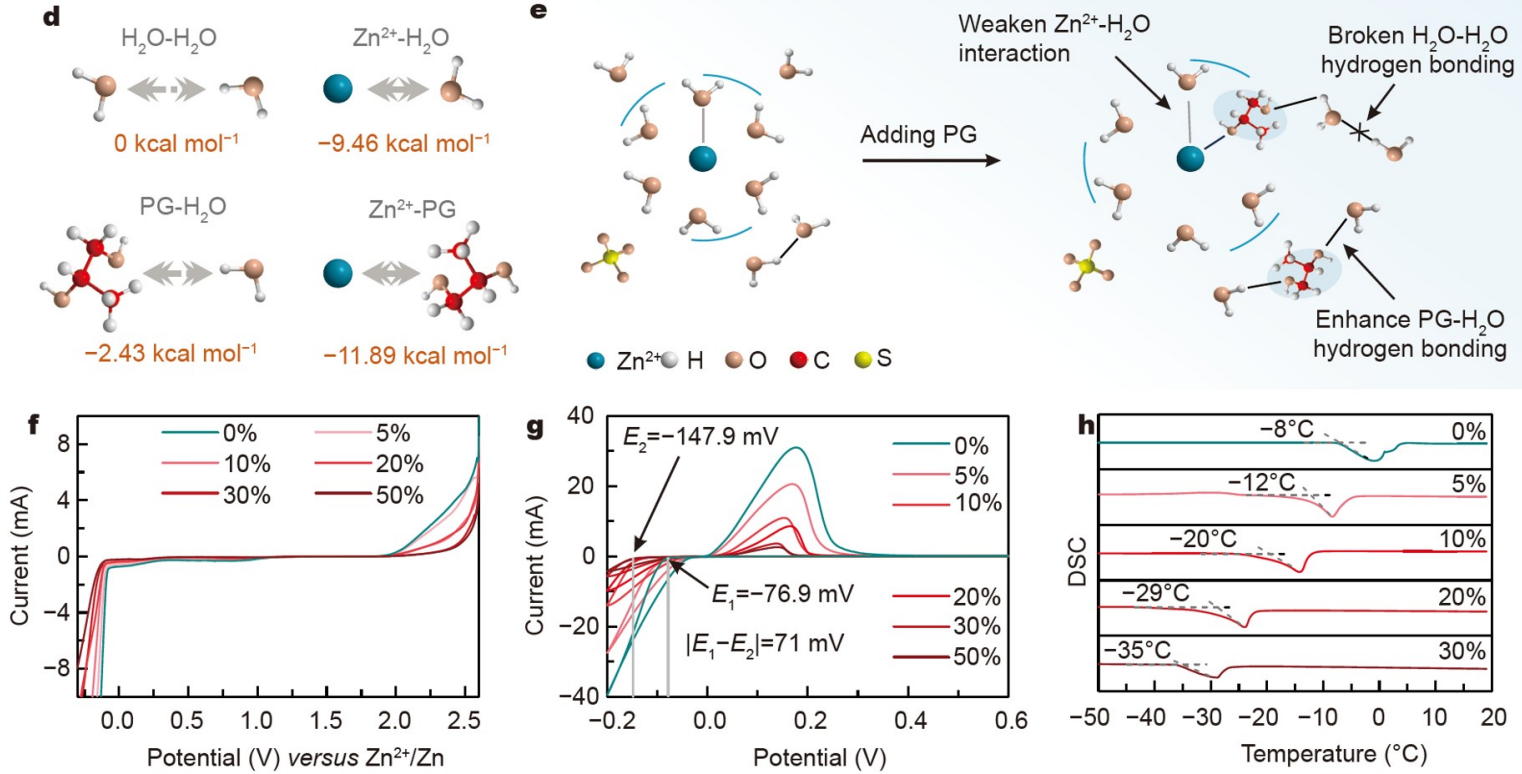

Figure 1 (a) FTIR spectra of $\mathrm{H}_{2} \mathrm{O}-x \mathrm{PG}(x=0 \%, 5 \%, 10 \%, 20 \%, 30 \%, 50 \%)$ solvent without $\mathrm{ZnSO}_{4}$, (b) ${ }^{1} \mathrm{H}-\mathrm{NMR}$ spectra of $\mathrm{ZnSO}_{4}-\mathrm{H}_{2} \mathrm{O}-x \mathrm{PG}$ electrolyte, (c) FTIR spectra of the $\mathrm{ZnSO}_{4}-\mathrm{H}_{2} \mathrm{O}-x$ PG electrolyte, (d) Relative binding energies between different molecules obtained from DFT calculation, (e) Schematic illustration on a possible mechanism of changes in the chemistry of hybrid electrolyte with PG, (f) LSV profiles of the electrolytes, (g) CV profiles of Zn// stainless steel cells, (h) DSC curves of the electrolytes.

cules, strengthen the $\mathrm{H}-\mathrm{O}$ covalent bond, and change the solvation structure of $\mathrm{Zn}^{2+}$, which inhibits water activity, improves the stability of electrolytes, and adjusts the $\mathrm{Zn}$ deposition.

The LSV and the ohmic-corrected CV were used to further investigate the effects of PG on electrolyte stability. As shown in Fig. 1f, the voltage stability window is expanded in $\mathrm{ZnSO}_{4} / \mathrm{H}_{2} \mathrm{O}$ / PG electrolyte with an increased oxygen evolution voltage, lower initial voltage of hydrogen evolution, and lower $\mathrm{Zn}$ deposition voltage than that without PG, resulting from the decreased water activity [44]. The CV curves of batteries with various electrolytes are shown in Fig. 1g. In the $\mathrm{ZnSO}_{4}$ electrolyte, the nucleation overpotential is $76.9 \mathrm{mV}$, but after adding PG, an increased nucleation overpotential is achieved ( $147.9 \mathrm{mV}, 50$ vol\% PG). The high nucleation overpotential corresponds to a doughty driving force for nucleating and will be likely to yield finegrained deposits, whereas the low nucleation overpotential has an opposite effect, that is, the deposits rapidly grow into dendrites due to the "tip effect" [45]. The morphology of $\mathrm{Zn}$ deposition in PG electrolytes can be greatly optimized due to the high nucleation overpotential [34]. Moreover, the peak intensity of $\mathrm{CV}$ profiles can reflect the reaction kinetics of electrolytes. The larger radii of complexes of $\left[\mathrm{Zn}\left(\mathrm{H}_{2} \mathrm{O}\right) m(\mathrm{PG}) n\right]^{2+}$ than that of $\left[\mathrm{Zn}\left(\mathrm{H}_{2} \mathrm{O}\right)_{6}\right]^{2+}$, which leads to a more sluggish diffusion of $\mathrm{PG}$ electrolyte, result in lower peak intensity in the $\mathrm{ZnSO}_{4} / \mathrm{H}_{2} \mathrm{O} / \mathrm{PG}$ electrolyte, implying slower reaction kinetics. [35]. This is further confirmed by the decreased ionic conductivity of the electrolytes (i.e., the conductivity of $\mathrm{Zn}^{2+}$ ) with the addition of PG (Fig. S1), which reduces the mass transfer process and prevents the rapid growth of $\mathrm{Zn}$ dendrites, benefiting a uniform deposition of $\mathrm{Zn}$ on the electrode surface and an improved performance in PG electrolyte. SEM images of the $\mathrm{Zn}$ electrode after deposition in hybrid electrolytes with a current density of $0.5 \mathrm{~mA} \mathrm{~g}^{-1}$ confirm the influence of $\mathrm{PG}$ on nucleation and growth of Zn. Fig. S2a shows the morphology of the Zn electrode deposited for $10 \mathrm{~min}$ with and without PG (30 vol\%), showing that the surface of the electrode in $\mathrm{ZnSO}_{4} / \mathrm{H}_{2} \mathrm{O}$ electrolyte is uneven with some big $\mathrm{Zn}$ dendrites in the size of $2-10 \mu \mathrm{m}$. The surface of the $\mathrm{Zn}$ electrode becomes smoother and denser and the deposited grains are finer and more uniform after adding PG, indicating the $\mathrm{Zn}$ deposition process is greatly adjusted by PG. The dendrites in the $\mathrm{ZnSO}_{4} / \mathrm{H}_{2} \mathrm{O}$ electrolyte become more severe when the deposition time is increased to $30 \mathrm{~min}$ (Fig. S2b). Furthermore, because of the alcohol's excellent antifreezing performance, the electrolytes' low-temperature properties were measured by freezing experiments and DSC analysis. Fig. S3 shows the photos of hybrid electrolytes at $-20^{\circ} \mathrm{C}$ for $24 \mathrm{~h}$, showing that the electrolyte without PG is frozen. When the amount of PG is beyond $10 \mathrm{vol} \%$, the electrolytes remain in a 
liquid state. The corresponding DSC analysis implies that the freezing points of $5 \%, 10 \%, 20 \%$, and $30 \%$ PG decrease to $-12^{\circ} \mathrm{C}$, $-20^{\circ} \mathrm{C},-29^{\circ} \mathrm{C}$, and $-35^{\circ} \mathrm{C}$, respectively, resulting from the broken hydrogen-bonding interaction between $\mathrm{H}_{2} \mathrm{O}$ molecules by PG (Fig. 1h). The excellent anti-freezing performance with PG is beneficial to service in some special conditions. The ionic conductivity decreased as the amount of PG increased, lowering the battery's overall performance. In the remaining experiments, 20 vol\% PG was used based on the ionic conductivity and freezing points, taking into account the battery's practical performance and low-temperature properties.

\section{Electrochemical properties of various electrolytes}

$\mathrm{Zn} / / \mathrm{Zn}$ symmetrical batteries were built under galvanostatic conditions at room temperature $\left(25^{\circ} \mathrm{C}\right)$ to investigate the effects of PG on long-term cycling stability. As illustrated in Fig. 2a and Fig. S4a, after cycling for $110 \mathrm{~h}$ at an areal capacity of $0.2 \mathrm{~mA} \mathrm{~h} \mathrm{~cm}^{-2}$ and $100 \mathrm{~h}$ at $1.0 \mathrm{~mA} \mathrm{~h} \mathrm{~cm}^{-2}$, the sudden short circuit appears in $\mathrm{ZnSO}_{4} / \mathrm{H}_{2} \mathrm{O}$ electrolyte with an irreversible decrease of the polarization voltage $(0 \mathrm{~V}$, insets of Fig. 2a). It is worth noting that the competitive gas evolution occurrs during the cycling process in the $\mathrm{ZnSO}_{4} / \mathrm{H}_{2} \mathrm{O}$ electrolyte, as verified by the obvious volume expansion of the cell (Fig. S5), which is caused by the narrow electrochemical stabilization window. Batteries treated with PG, on the contrary, exhibit stable polarization voltages with an extended cycling life (over $1000 \mathrm{~h}$ at $0.2 \mathrm{~mA} \mathrm{~h} \mathrm{~cm}^{-2}$ and over $300 \mathrm{~h}$ at $1.0 \mathrm{~mA} \mathrm{~h} \mathrm{~cm}^{-2}$ without any potential fluctuation or short circuit), which is expected to give the improved stability of electrolyte and suppresses the formation of $\mathrm{Zn}$ dendrites. In the enlarger profiles of certain cycles in $\mathrm{Zn} / / \mathrm{Zn}$ symmetrical batteries, the battery with $\mathrm{PG}$ exhibits a higher overpotential $(85 \mathrm{mV})$ than the battery in $\mathrm{ZnSO}_{4}$, which is associated with the ionic conductivity and can reflect the $\mathrm{Zn}$ deposition. The larger the overpotential is, the smoother $\mathrm{Zn}$ deposition is, thus resulting in the battery's stability [35]. Therefore, the battery with PG exhibits a smoother Zn deposition and more stable long-term cycling properties. The $\mathrm{Zn} / / \mathrm{Zn}$ symmetrical batteries were tested at high current densities of 1 and $2 \mathrm{~mA} \mathrm{~cm}^{-2}$ to further investigate the actual applicability of the electrolytes. Fig. $2 \mathrm{~b}$ and Fig. S4b show that the cycling life of $\mathrm{Zn} / / \mathrm{Zn}$ batteries is vastly longer with a steady cycle after adding $\mathrm{PG}$, while the voltage polarization occurs within $60 \mathrm{~h}$ cycles in $\mathrm{ZnSO}_{4}$ electrolyte. After $40 \mathrm{~h}$ of cycling $\left(0.2 \mathrm{~mA} \mathrm{~cm}{ }^{-2}\right.$, $0.2 \mathrm{~mA} \mathrm{~h} \mathrm{~cm}^{-2}$ ), the batteries were disassembled and the separator in PG electrolyte was cleaner than in the non-PG electrolyte (Fig. 2c and d). FESEM was used to characterize the surface morphology of cycled $\mathrm{Zn}$ electrode, illustrating that the surface of $\mathrm{Zn}$ electrode in the $\mathrm{ZnSO}_{4} / \mathrm{H}_{2} \mathrm{O}$ electrolyte is rough and irregular and there are many large particles with sizes of $2-30 \mu \mathrm{m}$, which can pierce the separator. Inversely, the surface of the electrode in 20 vol\% PG electrolyte is uniform, without large particle products.

We used electrochemical impedance spectroscopy (EIS) of $\mathrm{Zn} / / \mathrm{Zn}$ coin cells before and after cycling to assess the effect of PG on by-products (Fig. 2e and f). There is only one semi-circle in each of these EIS profiles, indicating a simple charge transfer at the electrode-electrolyte interphase [46]. The initial impedance values are similar, but after 40 -h cycling, the impedance value in the $\mathrm{ZnSO}_{4} / \mathrm{H}_{2} \mathrm{O}$ electrolyte increases significantly. The lower cycled impedance value in the PG electrolyte results from the inhibition effect of PG on by-products during cycling. Owing to the decreased water activity and the increased stable voltage window, fewer water molecules decompose, resulting in less $\mathrm{OH}^{-}$generation, which ultimately inhibits the generation of byproducts $\mathrm{Zn}_{4} \mathrm{SO}_{4}(\mathrm{OH})_{6} \cdot x \mathrm{H}_{2} \mathrm{O}$, as confirmed by XRD patterns of the cycled $\mathrm{Zn}$ electrode, in Fig. S6. The peak positions located at $12.1^{\circ}, 26.2^{\circ}$, and $24.5^{\circ}, 51.5^{\circ}$ are consistent with the standard PDF card of $\mathrm{Zn}_{4} \mathrm{SO}_{4}(\mathrm{OH})_{6} \cdot 6 \mathrm{H}_{2} \mathrm{O}$ and $\mathrm{Zn}_{4} \mathrm{SO}_{4}(\mathrm{OH})_{6} \cdot 3 \mathrm{H}_{2} \mathrm{O}$, respectively. After adding $\mathrm{PG}$ electrolyte, the peaks nearly vanish, indicating the inhibition of by-products in the PG electrolyte. As a result of the use of PG, the growth of by-products and dendrites can be inhibited, resulting in improved long-term cycling stability.

We fabricated $\mathrm{Cu} / / \mathrm{Zn}$ half-batteries to test the Coulombic efficiency (CE), using $\mathrm{Cu}$ as the working electrode and $\mathrm{Zn}$ as the counter and reference electrodes at a current density of $0.5 \mathrm{~mA} \mathrm{~cm}^{-2}$ and a cut-off voltage of $0.5 \mathrm{~V}$ to see how PG affected the $\mathrm{Zn}$ plating/stripping process. As illustrated in Fig. 3a, an average CE of $95 \%$ was obtained in the first 50 cycles with the $\mathrm{ZnSO}_{4}$ electrolyte and the CE fluctuated at the $52^{\text {nd }}$ cycle. Fig. $3 \mathrm{~b}$ shows the specific cycling voltage profiles in the $\mathrm{ZnSO}_{4}$ electrolyte, showing that the voltage is very unstable during cycling, which can lead to battery failure [47]. In contrast, $\mathrm{Cu} / / \mathrm{Zn}$ cells with the addition of PG display a significantly boosted CE and stable profiles (Fig. 3c), along with an average CE of $98.9 \%$ from the $21^{\text {st }}$ to $150^{\text {th }}$ cycles. Besides, the XRD pattern of the cycled $\mathrm{Cu}$ electrode in the $\mathrm{PG}$ electrolyte shows a relatively weak peak of $\mathrm{Zn}_{4} \mathrm{SO}_{4}(\mathrm{OH})_{6} \cdot 5 \mathrm{H}_{2} \mathrm{O}$, indicating that $\mathrm{PG}$ can inhibit the production of by-products (Fig. 3d). The deposited morphologies of $\mathrm{Zn}$ on $\mathrm{Cu}$ electrode after $20 \mathrm{~h}$ plating/stripping cycles were characterized by FESEM to further investigate the influence of PG (Fig. 3e and 3f). After $20 \mathrm{~h}$ cycles, the surface of the $\mathrm{Cu}$ electrode is smooth and uniform without big aggregates in the $\mathrm{PG}$ electrolyte, while the surface of the $\mathrm{Cu}$ electrode in the $\mathrm{ZnSO}_{4} / \mathrm{H}_{2} \mathrm{O}$ electrolyte is fluffy and uneven with many bulk aggregates in sizes of $1-5 \mu \mathrm{m}$, which can pierce the separator. EDS analysis was used to determine the exact elemental content, as shown in Fig. S7. In the $\mathrm{ZnSO}_{4} / \mathrm{H}_{2} \mathrm{O}$ electrolyte, distinct $\mathrm{S}$ element can be found on the electrode surface, indicating the formation of by-products. In contrast, deposited $\mathrm{Zn}$ surface in the $\mathrm{ZnSO}_{4} / \mathrm{H}_{2} \mathrm{O} / \mathrm{PG}$ electrolyte owns no S element and less $\mathrm{O}$ content, implying the inhibited formation of byproducts in the PG electrolyte, which is consistent with the XRD results. These results show that PG can improve the stability of the battery and adjust the formation of by-products and $\mathrm{Zn}$ dendrites.

\section{Characterization of $\mathrm{Zn} / / \mathrm{V}_{2} \mathrm{O}_{5}$ battery}

We built a zinc-ion battery using $\mathrm{V}_{2} \mathrm{O}_{5}$ powder as the cathode and $\mathrm{Zn}$ foil as the anode to demonstrate the versatility of PG/ $\mathrm{H}_{2} \mathrm{O}$ hybrid electrolytes in an aqueous zinc-based energy storage system. The XRD pattern of $\mathrm{S}-\mathrm{V}_{2} \mathrm{O}_{5}$ powder shows that the phase is pure and all peak positions correspond well with the standard crystalline phase of $\mathrm{V}_{2} \mathrm{O}_{5}$ (PDF \# 44-0674) (Fig. S8). Fig. $\mathrm{S} 9$ is the SEM image of the $\mathrm{S}-\mathrm{V}_{2} \mathrm{O}_{5}$ powder. To further evaluate the long-term cycling properties, $\mathrm{S}-\mathrm{V}_{2} \mathrm{O}_{5}$ powder was used as the cathode in the assembly of $\mathrm{Zn} / / \mathrm{V}_{2} \mathrm{O}_{5}$ full batteries.

Fig. 4a shows the cyclic stability and CE profiles of the $\mathrm{Zn} / /$ $\mathrm{V}_{2} \mathrm{O}_{5}$ battery at a current density of $5 \mathrm{~A} \mathrm{~g} \mathrm{~g}^{-1}$. The activation process of the $\mathrm{V}_{2} \mathrm{O}_{5}$ cathode causes the specific capacity to rapidly increase during the first 90 cycles. The battery with PG presents a high capacity of $225 \mathrm{~mA} \mathrm{~h} \mathrm{~g}^{-1}$ and capacity retention 

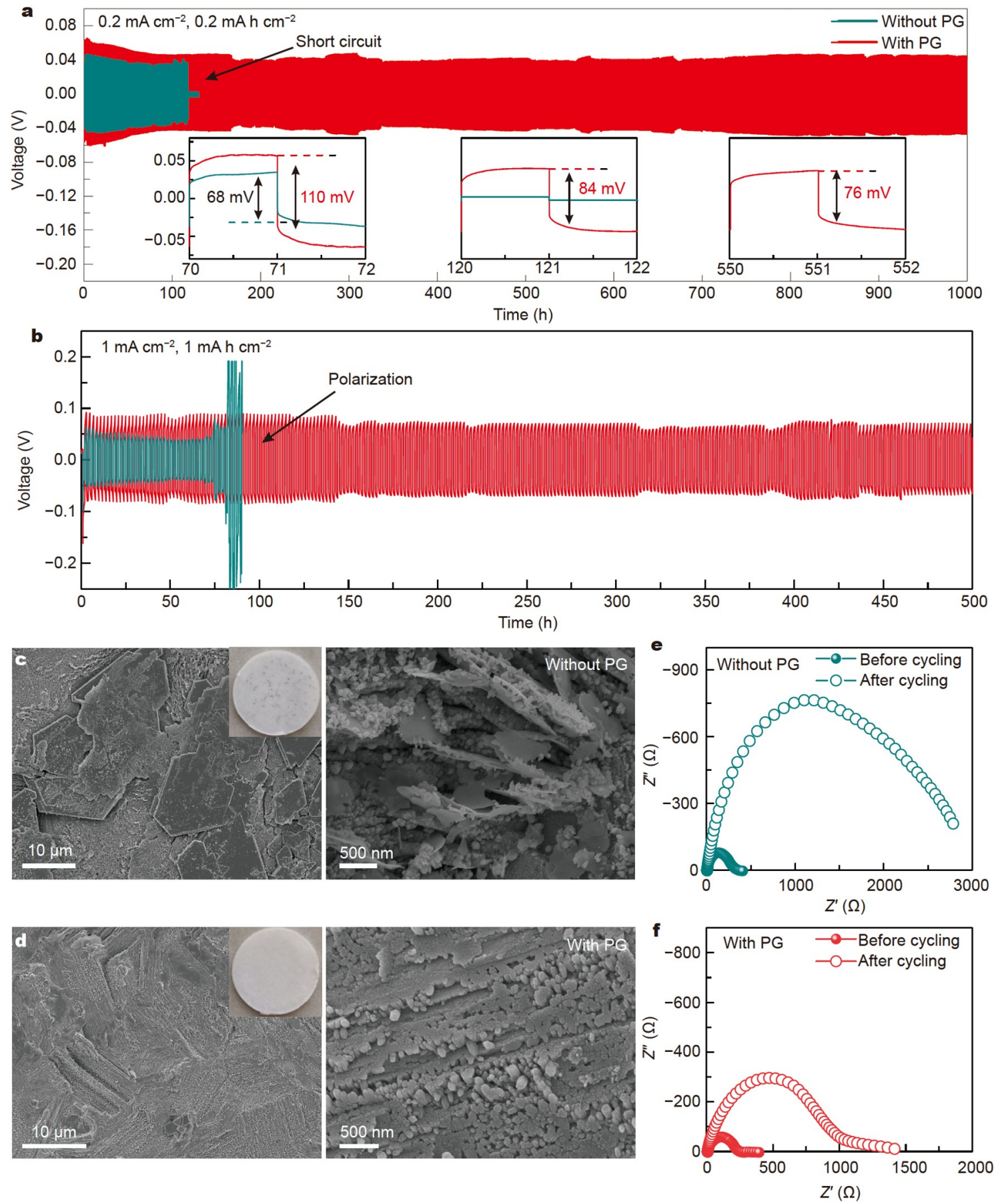

Figure 2 Characterizations of $\mathrm{Zn} / / \mathrm{Zn}$ symmetrical batteries with and without PG (20 vol\%): (a) Galvanostatic Zn plating/stripping in $\mathrm{Zn} / / \mathrm{Zn}$ symmetrical batteries with and without PG at a current density of $0.2 \mathrm{~mA} \mathrm{~cm}^{-2}$ and a capacity of $0.2 \mathrm{~mA} \mathrm{~h} \mathrm{~cm}{ }^{-2}$, (b) $\mathrm{Zn}$ plating/stripping in $\mathrm{Zn} / / \mathrm{Zn}$ symmetrical batteries at a high current density of $1 \mathrm{~mA} \mathrm{~cm}{ }^{-2}$ and capacity of $1 \mathrm{~mA} \mathrm{~h} \mathrm{~cm}^{-2}$, (c, d) SEM images of $\mathrm{Zn}$ electrode after $40 \mathrm{~h}$ cycles without and with PG, (e, f) EIS curves of $\mathrm{Zn} / / \mathrm{Zn}$ symmetric cells before and after $40 \mathrm{~h}$ cycles without and with PG.

of $92.6 \%$ after 5000 cycles, while the battery without PG only retains $29 \%$ of its initial capacity (the highest capacity after activation), which implies that better cycling performance is achieved with PG due to the inhibited water activity and dendrite growth. We tested the cyclic stability and efficiency at a low current density of $500 \mathrm{~mA} \mathrm{~g}^{-1}$ to further verify the effects of PG on the properties of a full battery (Fig. S10). After 300 cycles, the battery with PG delivered a discharge specific capacity of $348 \mathrm{~mA} \mathrm{~h} \mathrm{~g}^{-1}$, which is $96.9 \%$ retention of the initial capacity (the highest capacity after activation). The battery without PG, on the contrary, only retains $80 \%$ of its capacity, indicating that PG can improve the full battery's cycling stability. Long-term cycling performance at $-20^{\circ} \mathrm{C}$ was obtained to evaluate the battery's low-temperature properties. Fig. $4 \mathrm{~b}$ shows the longterm cycling profiles of the $\mathrm{Zn} / / \mathrm{V}_{2} \mathrm{O}_{5}$ battery at $-20^{\circ} \mathrm{C}$, showing that the battery with PG exhibits a stable specific capacity of $190 \mathrm{~mA} \mathrm{~h} \mathrm{~g}^{-1}$, while the capacity of the battery without PG drastically decreases to $0 \mathrm{~mA} \mathrm{~h} \mathrm{~g}$. The excellent anti-freezing 

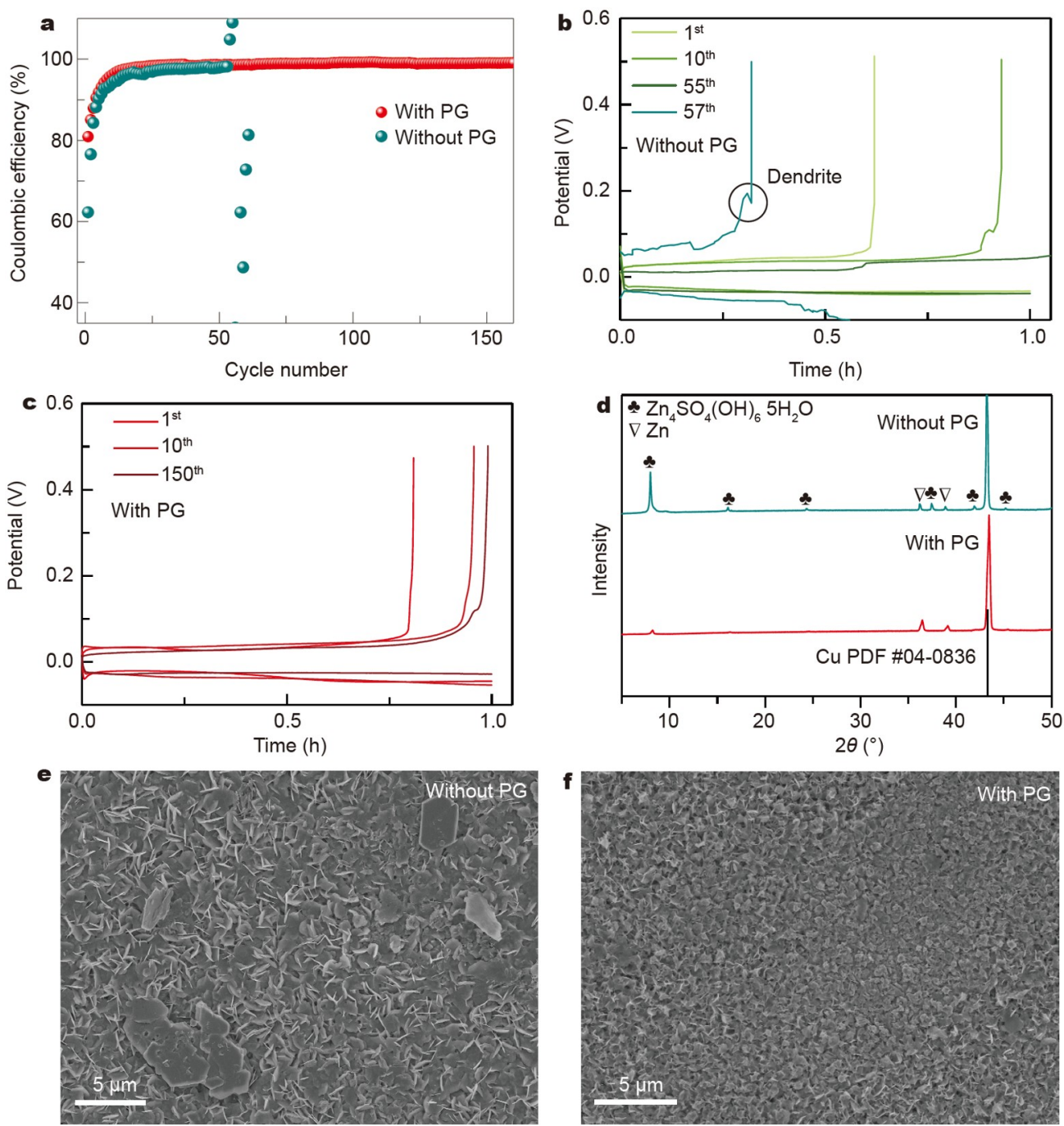

Figure 3 Characterizations of $\mathrm{Cu} / / \mathrm{Zn}$ batteries: (a) $\mathrm{CE}$ of $\mathrm{Zn}$ plating/stripping in different electrolytes, (b, c) voltage profiles of $\mathrm{Zn}$ plating/stripping processes at different cycles in electrolytes with and without PG, (d) XRD profiles of the Cu electrode after $20 \mathrm{~h}$ plating/stripping, (e, f) SEM images of the deposited $\mathrm{Zn}$ on $\mathrm{Cu}$ electrode after $20 \mathrm{~h}$ plating/stripping deposition without and with PG.

properties of PG electrolytes are caused by the broken hydrogen bonding between $\mathrm{H}_{2} \mathrm{O}$ molecules by PG. The GCD profiles with and without PG at the $2^{\text {nd }}$ cycle were carried out at a current density of $500 \mathrm{~mA} \mathrm{~g}^{-1}$ to see if PG affects the battery's oxidation/ reduction process. As shown in Fig. 4c, both profiles have the same charging/discharging plat voltages, suggesting that $\mathrm{PG}$ does not influence the oxidation/reduction process. CV profiles of $\mathrm{Zn} / / \mathrm{V}_{2} \mathrm{O}_{5}$ batteries with and without PG further confirm this result (Fig. 4d). Both profiles have two pairs of redox peaks, which means PG has no effects on the redox reaction. However, the gap between redox peak positions becomes bigger, implying the slower reaction kinetics of PG electrolyte, which is consistent with the results of ionic conductivity. Moreover, to explore whether PG influences cathode materials, the SEM and XRD analyses of the cycled cathode plates at $500 \mathrm{~mA} \mathrm{~g}^{-1}$ were applied. The morphologies of the cycled cathode in $20 \%$ PG electrolyte are identical to the pristine plate, while the pure $\mathrm{ZnSO}_{4}$ cathode shows slight dissolution and side products, according to SEM images (Fig. S11). The PG does not affect cathode materials, according to the XRD pattern (Fig. S12). We used $\mathrm{Zn} / / \mathrm{V}_{2} \mathrm{O}_{5}$ batteries with the $\mathrm{ZnSO}_{4} / \mathrm{PG}$ electrolyte to light several LED bulbs to test the battery's practical usability. As shown in Fig. 4e, the batteries can light several bulbs, suggesting the practical usability of PG in the battery. Those results indicate that PG has no effects on the redox reaction and can improve cycle stability and capacity, suggesting that PG is a superior additive.

\section{CONCLUSIONS}

In this study, the PG electrolyte was found to be able to regulate aqueous $\mathrm{Zn}^{2+}$ electrochemical reversibility on a molecular level, resulting in decreased water activity, inhibited $\mathrm{Zn}$ dendrite and side-reactions, and improved properties. The experiments and DFT calculations imply the PG has a stronger interaction with $\mathrm{Zn}^{2+}$ and $\mathrm{H}_{2} \mathrm{O}$ than water. Following the addition of PG, water molecules interact with PG, lowering water activity and the freezing point and inhibiting the decomposition of solvated $\mathrm{H}_{2} \mathrm{O}$, resulting in a wider electrochemical stability window and less parasitic reactions. In addition, $\mathrm{PG}$ replaces solvated $\mathrm{H}_{2} \mathrm{O}$ in the $\mathrm{Zn}^{2+}$ solvation cells, weakening the $\mathrm{Zn}^{2+}$ solvation in the electrolyte and improving the cycling stability. When $20 \mathrm{vol} \%$ PG was added into $3 \mathrm{~mol} \mathrm{~L}^{-1} \mathrm{ZnSO}_{4}$ aqueous electrolyte, high cycling stability over $1000 \mathrm{~h}$ in the $\mathrm{Zn} / / \mathrm{Zn}$ symmetric battery 

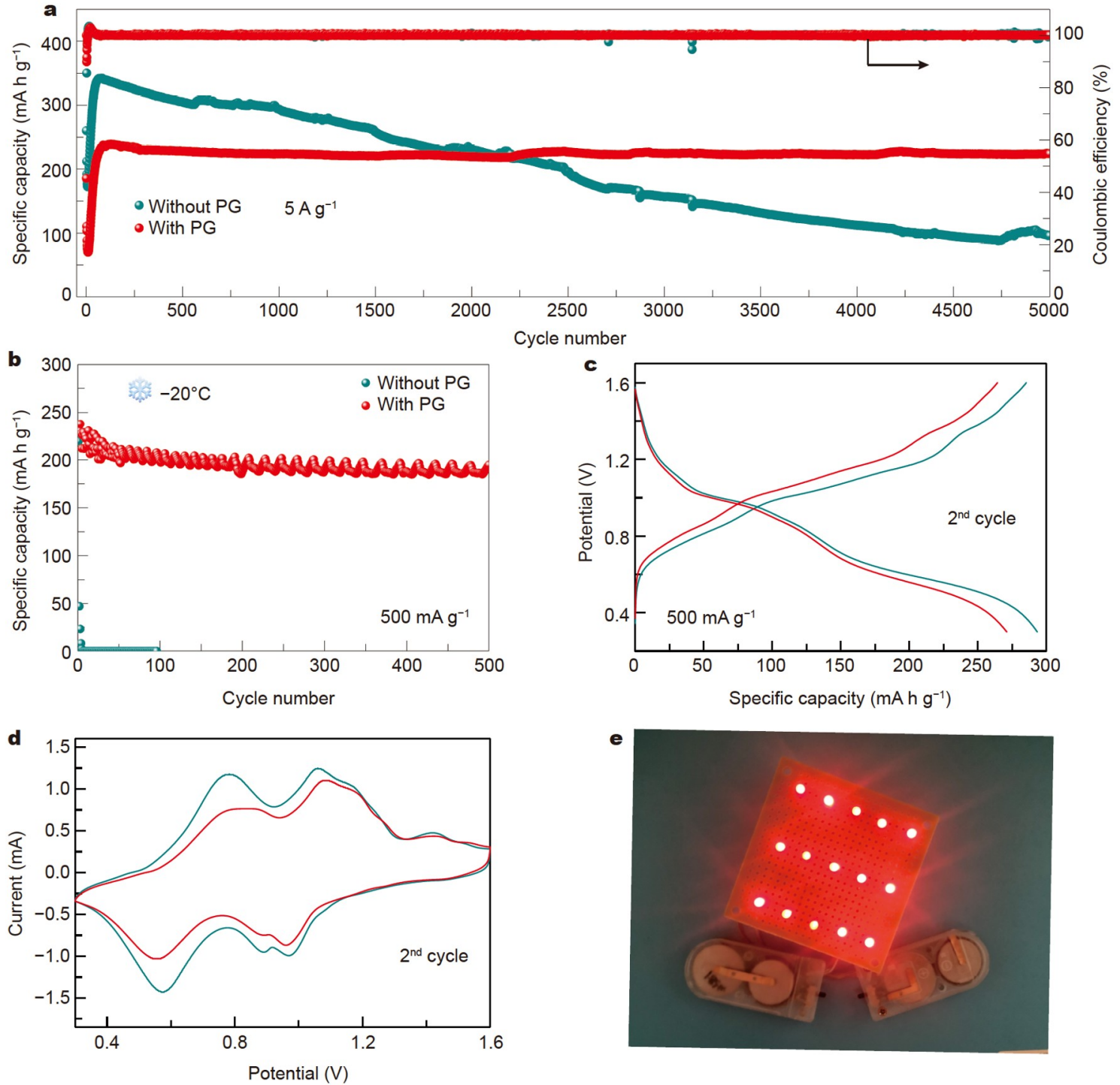

Figure 4 Cycling stability and performance of the $\mathrm{Zn} / / \mathrm{V}_{2} \mathrm{O}_{5}$ battery: (a) long-term cycling performance of the $\mathrm{Zn} / / \mathrm{V}_{2} \mathrm{O}_{5}$ battery at $5 \mathrm{~A} \mathrm{~g} \mathrm{~g}^{-1}$, (b) the lowtemperature properties of the $\mathrm{Zn} / / \mathrm{V}_{2} \mathrm{O}_{5}$ battery at $-20^{\circ} \mathrm{C}$, (c) GCD curves of the $\mathrm{Zn} / / \mathrm{V}_{2} \mathrm{O}_{5}$ battery at $2^{\text {nd }}$ cycling with a current density of $500 \mathrm{~mA} \mathrm{~g}^{-1}$, (d) $\mathrm{CV}$ profiles of the $\mathrm{Zn} / / \mathrm{V}_{2} \mathrm{O}_{5}$ battery at $2^{\text {nd }}$ cycling with a scan rate of $0.1 \mathrm{mV} \mathrm{s}^{-1}$, (e) working picture of lights with the $\mathrm{Zn} / / \mathrm{V}_{2} \mathrm{O}_{5}$ battery.

and significant average $\mathrm{CE}$ of $98.9 \%$ in the $\mathrm{Cu} / / \mathrm{Zn}$ cell were achieved. The effectiveness of PG electrolyte is valid in the $\mathrm{Zn} / /$ $\mathrm{V}_{2} \mathrm{O}_{5}$ battery. The battery exhibited a stable specific capacity of $348 \mathrm{~mA} \mathrm{~h} \mathrm{~g}^{-1}$ at $500 \mathrm{~mA} \mathrm{~g}^{-1}$ and superior long-term cycling stability with $92.6 \%$ capacity retention over 5000 cycles at $5 \mathrm{~A} \mathrm{~g}^{-1}$, which are prominently higher than that without PG. Over 500 cycles at $-20^{\circ} \mathrm{C}$, the battery with PG maintained a stable specific capacity of $190 \mathrm{~mA} \mathrm{~h} \mathrm{~g}^{-1}$ at $0.5 \mathrm{~A} \mathrm{~g}^{-1}$, demonstrating an excellent low-temperature performance.

\section{Received 1 September 2021; accepted 21 October 2021; published online 8 December 2021}

1 Deng W, Zhou Z, Li Y, et al. High-capacity layered magnesium vanadate with concentrated gel electrolyte toward high-performance and wide-temperature zinc-ion battery. ACS Nano, 2020, 14: 15776-15785

2 Li Z, Peng Y, Zhang X, et al. Oxygen vacancies enhance lithium-ion storage properties of $\mathrm{TiO}_{2}$ hierarchical spheres. Batteries Supercaps, 2021, doi: 10.1002/batt.202100157

3 Hyun WJ, Thomas CM, Luu NS, et al. Layered heterostructure ionogel electrolytes for high-performance solid-state lithium-ion batteries. Adv Mater, 2021, 33: 2007864

4 Klein S, Harte P, Henschel J, et al. On the beneficial impact of $\mathrm{Li}_{2} \mathrm{CO}_{3}$ as electrolyte additive in NCM523/graphite lithium ion cells under highvoltage conditions. Adv Energy Mater, 2021, 11: 2003756

5 Chen P, Yuan X, Xia Y, et al. An artificial polyacrylonitrile coating layer confining zinc dendrite growth for highly reversible aqueous zinc-based batteries. Adv Sci, 2021, 8: 2100309

6 Liu YY, Lv TT, Wang $\mathrm{H}$, et al. Nsutite-type $\mathrm{VO}_{2}$ microcrystals as highly durable cathode materials for aqueous zinc-ion batteries. Chem Eng J, 2021, 417: 128408

7 Zeng X, Hao J, Wang Z, et al. Recent progress and perspectives on aqueous $\mathrm{Zn}$-based rechargeable batteries with mild aqueous electrolytes. Energy Storage Mater, 2019, 20: 410-437

8 Li Z, Peng Y, Liu C, et al. Oxygen-deficient $\mathrm{TiO}_{2}$ yolk-shell spheres for enhanced lithium storage properties. Energy Environ Mater, 2021, doi: 10.1002/eem2.12156

9 Jia X, Liu C, Neale ZG, et al. Active materials for aqueous zinc ion batteries: synthesis, crystal structure, morphology, and electrochemistry. Chem Rev, 2020, 120: 7795-7866

10 Wan F, Zhou X, Lu Y, et al. Energy storage chemistry in aqueous zinc 
metal batteries. ACS Energy Lett, 2020, 5: 3569-3590

11 Cao Z, Zhuang P, Zhang X, et al. Strategies for dendrite-free anode in aqueous rechargeable zinc ion batteries. Adv Energy Mater, 2020, 10: 2001599

12 Liu C, Neale Z, Zheng J, et al. Expanded hydrated vanadate for highperformance aqueous zinc-ion batteries. Energy Environ Sci, 2019, 12: 2273-2285

$13 \mathrm{Xu} \mathrm{W,} \mathrm{Wang} \mathrm{Y.} \mathrm{Recent} \mathrm{progress} \mathrm{on} \mathrm{zinc-ion} \mathrm{rechargeable} \mathrm{batteries.}$ Nano-Micro Lett, 2019, 11: 90

14 Zhao $\mathrm{Y}$, Wang $\mathrm{D}$, Li X, et al. Initiating a reversible aqueous $\mathrm{Zn} /$ sulfur battery through a "liquid film". Adv Mater, 2020, 32: 2003070

15 Qiu N, Yang Z, Xue R, et al. Toward a high-performance aqueous zinc ion battery: Potassium vanadate nanobelts and carbon enhanced zinc foil. Nano Lett, 2021, 21: 2738-2744

16 Ding $\mathrm{Y}$, Peng $\mathrm{Y}$, Chen $\mathrm{W}$, et al. $\mathrm{V}$-MOF derived porous $\mathrm{V}_{2} \mathrm{O}_{5}$ nanoplates for high performance aqueous zinc ion battery. Appl Surf Sci, 2019, 493: 368-374

17 Lv TT, Liu YY, Wang $\mathrm{H}$, et al. Crystal water enlarging the interlayer spacing of ultrathin $\mathrm{V}_{2} \mathrm{O}_{5} \cdot 4 \mathrm{VO}_{2} \cdot 2.72 \mathrm{H}_{2} \mathrm{O}$ nanobelts for high-performance aqueous zinc-ion battery. Chem Eng J, 2021, 411: 128533

18 Cao L, Li D, Deng T, et al. Hydrophobic organic-electrolyte-protected zinc anodes for aqueous zinc batteries. Angew Chem Int Ed, 2020, 59: 19292-19296

19 Hao J, Li X, Zhang S, et al. Designing dendrite-free zinc anodes for advanced aqueous zinc batteries. Adv Funct Mater, 2020, 30: 2001263

20 Zhang Q, Luan J, Fu L, et al. The three-dimensional dendrite-free zinc anode on a copper mesh with a zinc-oriented polyacrylamide electrolyte additive. Angew Chem Int Ed, 2019, 58: 15841-15847

21 Li C, Shi X, Liang S, et al. Spatially homogeneous copper foam as surface dendrite-free host for zinc metal anode. Chem Eng J, 2019, 379: 122248

22 Yuan D, Manalastas Jr. W, Zhang L, et al. Lignin@nafion membranes forming $\mathrm{Zn}$ solid-electrolyte interfaces enhance the cycle life for rechargeable zinc-ion batteries. ChemSusChem, 2019, 12: 4889-4900

23 Chen S, Lan R, Humphreys J, et al. Salt-concentrated acetate electrolytes for a high voltage aqueous $\mathrm{Zn} / \mathrm{MnO}_{2}$ battery. Energy Storage Mater, 2020, 28: 205-215

24 Wan F, Zhu J, Huang S, et al. High-voltage electrolytes for aqueous energy storage devices. Batteries Supercaps, 2020, 3: 323-330

25 Han J, Zarrabeitia M, Mariani A, et al. Halide-free water-in-salt electrolytes for stable aqueous sodium-ion batteries. Nano Energy, 2020, 77: 105176

26 Yang W, Du X, Zhao J, et al. Hydrated eutectic electrolytes with ligandoriented solvation shells for long-cycling zinc-organic batteries. Joule, 2020, 4: 1557-1574

27 Zhou W, Chen J, Chen M, et al. An environmentally adaptive quasisolid-state zinc-ion battery based on magnesium vanadate hydrate with commercial-level mass loading and anti-freezing gel electrolyte. J Mater Chem A, 2020, 8: 8397-8409

28 Bayaguud A, Luo X, Fu Y, et al. Cationic surfactant-type electrolyte additive enables three-dimensional dendrite-free zinc anode for stable zinc-ion batteries. ACS Energy Lett, 2020, 5: 3012-3020

29 Wang F, Borodin O, Gao T, et al. Highly reversible zinc metal anode for aqueous batteries. Nat Mater, 2018, 17: 543-549

30 Cao $\mathrm{L}, \mathrm{Li} \mathrm{D}, \mathrm{Hu} \mathrm{E}$, et al. Solvation structure design for aqueous $\mathrm{Zn}$ metal batteries. J Am Chem Soc, 2020, 142: 21404-21409

31 Huang S, Zhu J, Tian J, et al. Recent progress in the electrolytes of aqueous zinc-ion batteries. Chem Eur J, 2019, 25: 14480-14494

32 Hao J, Yuan L, Ye C, et al. Boosting zinc electrode reversibility in aqueous electrolytes by using low-cost antisolvents. Angew Chem Int Ed, 2021, 60: 7366-7375

33 Chang N, Li T, Li R, et al. An aqueous hybrid electrolyte for lowtemperature zinc-based energy storage devices. Energy Environ Sci, 2020, 13: 3527-3535

34 Li F, Yu L, Hu Q, et al. Fabricating low-temperature-tolerant and durable $\mathrm{Zn}$-ion capacitors via modulation of co-solvent molecular interaction and cation solvation. Sci China Mater, 2021, 64: 1609-1620

35 Qin $\mathrm{R}$, Wang $\mathrm{Y}$, Zhang $\mathrm{M}$, et al. Tuning $\mathrm{Zn}^{2+}$ coordination environment to suppress dendrite formation for high-performance $\mathrm{Zn}$-ion batteries. Nano Energy, 2021, 80: 105478

36 Demyanovich RJ, Lynn S. Prediction of infinite dilution activity coefficients of sulfur dioxide in organic solvents. J Solution Chem, 1991, 20: 693-701

37 Harifi-Mood AR, Sharifi F, Bijanzadeh HR. ${ }^{23} \mathrm{Na}-\mathrm{NMR}$ data based donor number and their correlation with solvatochromic parameters in binary solvent mixtures. ChemistrySelect, 2021, 6: 600-608

38 Zhang JB, Zhang PY, Ma K, et al. Hydrogen bonding interactions between ethylene glycol and water: density, excess molar volume, and spectral study. Sci China Ser B-Chem, 2008, 51: 420-426

39 Kumar RM, Baskar P, Balamurugan K, et al. On the perturbation of the $\mathrm{H}$-bonding interaction in ethylene glycol clusters upon hydration. J Phys Chem A, 2012, 116: 4239-4247

40 Xie J, Liang Z, Lu YC. Molecular crowding electrolytes for high-voltage aqueous batteries. Nat Mater, 2020, 19: 1006-1011

41 Jora MZ, Cardoso MVC, Sabadini E. Dynamical aspects of water-poly (ethylene glycol) solutions studied by ${ }^{1} \mathrm{H}$ NMR. J Mol Liquids, 2016, 222: 94-100

42 Yang H, Chang Z, Qiao Y, et al. Constructing a super-saturated electrolyte front surface for stable rechargeable aqueous zinc batteries. Angew Chem Int Ed, 2020, 59: 9377-9381

43 Ming J, Cao Z, Wahyudi W, et al. New insights on graphite anode stability in rechargeable batteries: Li ion coordination structures prevail over solid electrolyte interphases. ACS Energy Lett, 2018, 3: 335-340

44 Zhao Q, Yang J, Liu M, et al. Tuning electronic push/pull of Ni-based hydroxides to enhance hydrogen and oxygen evolution reactions for water splitting. ACS Catal, 2018, 8: 5621-5629

45 Zhao Z, Zhao J, Hu Z, et al. Long-life and deeply rechargeable aqueous $\mathrm{Zn}$ anodes enabled by a multifunctional brightener-inspired interphase. Energy Environ Sci, 2019, 12: 1938-1949

46 Zhao K, Wen M, Dong Y, et al. Thermal induced strain relaxation of 1D iron oxide for solid electrolyte interphase control and lithium storage improvement. Adv Energy Mater, 2016, 7: 1601582

47 Pan $\mathrm{H}$, Shao Y, Yan $\mathrm{P}$, et al. Reversible aqueous zinc/manganese oxide energy storage from conversion reactions. Nat Energy, 2016, 1: 16039

Acknowledgements This work was supported by the National Key R\&D Program of China (2017YFE0133800), the CASHIPS Director's Fund (YZJJ201902 and YZJJZX202018), and Anhui Provincial Natural Science Foundation (1908085QB52 and 2008085ME135).

Author contributions Wei T conceived and designed the experiments. Wei T, Peng Y, Li Z, and Hu L contributed to the experiment and data analysis. Mo L and Chen S contributed to the photographing. Ghadari R contributed to the DFT calculation. Wei T and Li Z contributed to the writing. All the authors contributed to the general discussion.

Conflict of interest The authors declare no competing financial interest.

Supplementary information The DFT calculation details and supporting data are available in the online version of the paper.

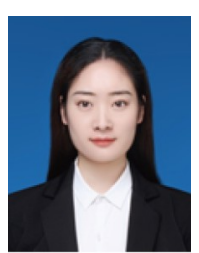

Tingting Wei is a $\mathrm{PhD}$ candidate at Hefei Institutes of Physical Science (HFIPS), Chinese Academy of Sciences (CAS), China, under the supervision of Prof. Linhua Hu. Her research interest focuses on aqueous zinc-ion batteries. 


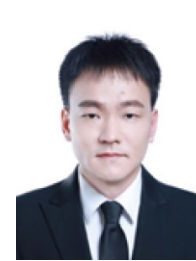

Zhaoqian Li is currently an associate professor at HFIPS, CAS, China. He received his $\mathrm{PhD}$ degree from Nanjing University in 2013, followed by a postdoc at HFIPS, CAS. From 2018 to 2020, He carried out his postdoctoral research in Prof. Guozhong Cao's group at the University of Washington (Seattle). His research interest focuses on aqueous zinc-ion batteries, lithium (sodium)-ion batteries, etc.



Linhua $\mathrm{Hu}$ received his $\mathrm{BSc}$ and $\mathrm{PhD}$ degrees from Anhui University and HFIPS, CAS. From 2007 to 2015, he worked as a research assistant and associate researcher in HFIPS, CAS. In 2014, he worked as a visiting professor at École Polytechnique Fédérale de Lausanne (EPFL), Switzerland. In 2015, he became a researcher in HFIPS, CAS. His research group works on nanostructured materials and their applications in photovoltaic and energy storage.
丙二醇电解液键结构调控及其水系锌离子电池稳定 性研究

韦婷婷 ${ }^{1,2}$, 彭昱琦 ${ }^{1,2}$, 莫立娥 1,2 , 陈双宏 ${ }^{1}$, Rahim Ghadari ${ }^{3}$, 李兆乾 ${ }^{*}$, 胡林华 $1^{*}$

摘要 水系锌基电池具有低成本和高安全性的优点, 是很有潜力的储 能技术. 然而, 枝晶、副反应和较差的低温性能限制了其实际应用, 这 与电解液的溶液组成密切相关. 在本工作中, 我们通过调控丙二醇电解 液的溶剂结构及键相互作用, 有效抑制了锌枝晶和副反应. 丙二醇具有 较高的电子云密度和DN (Donor number) 值, 可以破坏水分子间和水 分子与 $\mathrm{Zn}^{2+}$ 间的相互作用, 从而提高 $\mathrm{H}-\mathrm{O}$ 共价键的强度, 降低水活性和 冰点, 改变 $\mathrm{Zn}^{2+}$ 的溶剂化结构. 制备的电池器件表现出高的循环稳定性 ( $\mathrm{Zn} / / \mathrm{Zn}$ 电池循环超过 $1000 \mathrm{~h}$ ), 高可逆性(库伦效率达到 $98.9 \%$ ), 高储锌 性能(在 $5 \mathrm{~A} \mathrm{~g}^{-1}$ 下比容量为 $225 \mathrm{~m} \mathrm{~A} \mathrm{~h} \mathrm{~g}^{-1}$, 循环 5000 圈容量保持率为 $92.6 \%$ ) 和优异的防冻性能 (在 $-20^{\circ} \mathrm{C}$ 下循环 500 圈比容量为 $190 \mathrm{~mA} \mathrm{~h} \mathrm{~g}^{-1}$ ). 本工作为高性能水系锌离子电池的发展提供了一种有 前景的策略. 